\title{
Biological Capital, User Costs and the Productivity of Insecticides in Cotton Farming Systems in Sub-Saharan Africa
}

\author{
Oluyede Clifford Ajayi \\ International Centre for Research in Agroforestry (ICRAF), c/o Chitedze Agricultural Research Station, \\ Lilongwe, Malawi
}

\begin{abstract}
This study presents a conceptual framework and then uses field data collected in cotton fields of Côte d'Ivoire to illustrate the dynamics of the interaction between insecticides use, natural biological capital and the productivity of insecticides over time. Results show that the divergence between insecticide productivity estimates on one hand and, public concern that insecticides are overused on the other hand may not be attributed exclusively to functional specification of estimation models. However, some insights into resolving the paradox can be gained through disaggregation of the estimates (e.g. by chemical use history) and interpreting them in the context of the inter-temporal changes that have occurred in the biological capital of production systems over time. A disaggregation of the marginal value products of insecticide by chemical use history shows that in the zones where insecticides have been used for a longer period and crop diversity is narrower, the marginal value products of insecticides are consistently higher due to lower biodiversity which raises the economic importance of the chemical in such zones. To ensure long term sustainability of cotton in the region, the study recommends the promotion of targeted insecticide management practices that takes cognisance of the differences in the amount of biological capital and the economic value of the potential crop yield that would be saved by the chemical application in the different production systems. It also recommends that panel data consisting of entomological and the state of the agro-ecosystem being studied should be collected concurrently with agro-economic data and integrated into models for estimating insecticides' productivity.
\end{abstract}

Keywords: agro-ecosystem process, biological capital, Côte d'Ivoire, cotton, damage functions, insecticide productivity, production economics

\section{Introduction}

In the debate on food security and agricultural productivity growth in Sub-Saharan Africa, pest management is recognised as an important factor because yield loss due to pests may exceed a half of potential production depending on the level of pest pressure in a given season. In cotton, use of insecticides has continuously been a major issue. Although the potential for reduction in insecticide use and increased yields through transgenic cotton has been reported in Asia (Qaim, 2003; Qaim \& Zilberman, 2003), the prospects of transgenic varieties are low in most countries of Sub-Saharan Africa because potential profits of the seed supply industry are likely to be unattractive for a broad private sector engagement in the immediate future. Issues on risk management and overcoming acceptance problems of transgenic varieties (Qaim \& Zilberman, 2003) are likely to be comparatively more critical in Sub-Saharan Africa. As a result, insecticides will most probably continue to be a key method of pest control Sub-Saharan Africa in the foreseeable future. The implications of the use of insecticides on biological processes and estimates of the long-term productivity of the chemical in the region deserve attention.

Information on the productivity of insecticides provides insights into the debate on food security and food safety and, helps to identify appropriate policies on pest management. In the literature, productivity of insecticides has usually been estimated in a production function framework (Campbell, 1976; Headley, 1968; Rola \& Pingali, 1993) or damage abatement framework (Lichtenberg \& Zilberman, 1986) that considers the role of insecticides as damage control agents rather than a (conventional) yield increasing inputs. The results from these studies indicate that for a dollar expenditure on insecticides, a farmer obtains substantial benefits ranging from $\$ 4$ (Headley, 1968) and \$12 per dollar worth of insecticide used (Campbell, 1976). Strict economic 
interpretation of these estimates suggests that more insecticides should be used and any restriction on the use of the chemical will be quite costly in terms of the output that would be forgone. The problem however is that these results from insecticide productivity assessments are at variance with case studies on integrated pest management and public concern that insecticides are overused.

This paper addresses this problem by responding in particular to three questions: (1) Why do productivity estimates of insecticides often diverge from anecdotal observations and public concern that insecticides are overused? (2) What are the shortcomings in the economic interpretation of insecticide productivity assessments obtained from conventional and modified production function approach without recourse to biological processes? (3) Is the use of insecticides in cotton in West Africa in conflict with the concept of sustainable natural resources management? In answering these questions, the implications of biological processes in the estimation and interpretation of economic evaluations of insecticides productivity is used as a general hypothesis in this study. The paper begins by presenting an overview of the theoretical and empirical explanations that existing literature provides to the questions above. Then the dynamics of the relationship between the use of insecticides and natural biological processes are explained. Finally, the concept of the relationship is applied to field data collected in the major cotton production zones of Côte d'Ivoire.

\section{Overview of Insecticide Productivity Assessments}

Results of earlier economic studies (Campbell, 1976; Headley, 1968) on insecticide productivity conclude that the value of the crop yield that is saved by insecticides exceeds the cost incurred. The results generated a lot of debate because they imply that farmers can improve the profit of their fields if they increase the quantity of insecticides they use in their farms. Explanations have been put forward to elucidate the implications of the results, given public perceptions that insecticides are already overused. Some studies point out that unlike conventional yield increasing farm inputs, insecticides are riskreducing agents that provide means of insurance for farmers against pest attacks (Mumford, 1981). The studies identified 'insurance' as an important motive for farmers using insecticides, and posit that beyond cost and benefit considerations, risk-averse farmers will always opt for inputs like insecticides that minimise variance in farm production. However, a literature review by Pannell (1991) on the impact of insecticides on farm risks and empirical studies (e.g. Hurd, 1994) indicate that risk aversion does not necessarily lead to an increase in insecticide use by individual farmers. To provide further insights on insecticides and risk, Regev (1988) reports that insecticides can be either a risk-reducing or a risk-increasing input depending on the time horizon being considered, i.e. while insecticides may reduce variability in yields in the short run, they may increase production uncertainties (and risk) in the long run. The long-term risks arise from increased probability of pest outbreak due to pest resistance and increased probability of pest infestation due to inadvertent decimation of natural predators.

Lichtenberg and Zilberman (1986) introduced a new perspective in the estimation of insecticide productivity. They pointed out that wrong specification of production function models used in previous studies is a source of explanation for the high estimates of the productivity of insecticides. They show that insecticides are damage control agents, and models to analyse their productivity should be specified in a damage function framework to highlight this distinction from those of conventional yield increasing farm inputs e.g. land and labour. They demonstrated that if important physical and biological properties of damage control agents were not incorporated in specifying functional forms of production models to take account of this difference, estimates would be biased upwards. Further explanations concerning model specification errors in the analysis of insecticide productivity were provided by Blackwell and Pagoulatos (1992). Empirical studies that were carried out to evaluate insecticide productivity based on the modified model specifications however show that the explanation for high productivity estimates in earlier studies cannot be based exclusively on model specification form (Carpentier \& Weaver, 1997; Carrasco-Tauber \& Moffit, 1992). The literature is thus inconclusive regarding how the productivity of insecticides can be best estimated within a production economics framework. In the following section, 
ecosystem processes and the role of biological capital are introduced as important issues that need to be highlighted in the estimation and interpretation of insecticide productivity.

\section{Biological Capital Degradation and Estimation of Insecticide Productivity}

\section{Biological capital costs of insecticides}

In addition to the direct purchase cost of insecticides, there are indirect costs associated with the use of the chemical. These range from human health costs (borne by the farm especially where spraying is carried out by household members) to costs associated with the degradation of the environmental processes, loss of biodiversity and pollution of water sources among others (which are largely borne by society). Pimental et al. (1993) identified and provided estimates of these cost using the USA as a case study. This present study highlights biological capital cost as one type of cost associated with the use of insecticides but which has received less attention in the discussion of insecticides productivity.

When insecticides are used, two categories of costs are incurred. The first are the obvious and direct monetary costs involved in managing pests, such as the cost of purchase of the chemical and wages paid to carry out spraying. The second (and usually less obvious) is the resource cost that arises from gradual deterioration of biological capital resources in ecosystems due to continuous use of insecticides. Optimal decision on the use of insecticides is taken when the management of both the direct costs of pest control and the associated indirect cost on biological capital are optimised (Hueth \& Regev, 1974).

Several biological studies (e.g. Altieri, 1993; McLaughlin \& Mineau, 1995; Relyea, 2005) reveal the existence of biological capital resources that provide a natural regulatory mechanism in ecosystems. The biological capital resources exist in two major forms: biodiversity (renewable capital) and pest susceptibility (non-renewable capital). As a first step to introduce the concept of biological capital in insecticide productivity assessments, a discussion on is provided below on the two types of biological capital and how they are affected by continuous use of insecticides over time.

\section{Biodiversity (renewable) biological capital}

Biodiversity is a salient feature of traditional farming systems that performs a variety of renewal processes and ecological services in agro-ecosystems (Altieri, 1993). Through the presence of predators, biodiversity maintains pest and predator populations in a reasonable balance within the ecosystem. From an economic point of view these beneficial organisms are a renewable natural capital. When insecticides are applied, predators are negatively affected leading to a gradual loss of this form of natural capital over time (McLaughlin \& Mineau, 1995; Relyea, 2005). The extent of depletion of the biological capital is determined by the difference between the rate at which the predators are killed and the rate at which they can be replenished (i.e. from the wider ecosystem). As the renewable biological capital is depleted, the need for external chemical inputs to reinforce the regulatory mechanism within the ecosystem increases. As a result, the economic importance and productivity of insecticides increases over time. The relationship between the degradation of biological capital and the productivity of insecticides is illustrated in Figure 1.

In Figure 1, two extreme scenarios of insect damage to farm production are presented - the best and worst cases. In the best scenario represented by $\mathrm{Y}^{\max }$, it is assumed that there are no insects at all and hence no yield loss from insect attack. A typical farmer can attain a production level of $Y^{\max }$ or the maximum potential yield obtainable. As a result, insecticide does not have any economic importance and its productivity is nil. The magnitude of $\mathrm{Y}^{\max }$ will be determined exclusively by the level of use of conventional inputs (land, labour, fertiliser, management) but not by insect damage or chemical use. In the worst scenario represented by $\mathrm{Y}^{0}$, it is assumed that there is an occurrence of the most severe attack by insects, leading to a complete yield loss (i.e. zero production). In this scenario, insecticide becomes extremely important and the economic productivity of using it will increase commensurately.

However, the actual level of yield that a farmer gets is usually greater than zero due to biodiversity and several biological processes that play regulatory roles to control pests within the ecosystem. In reality, the actual yield lies between the two extreme scenarios, say at point $Y^{A}$. The totality of the potential yield loss can be broken 


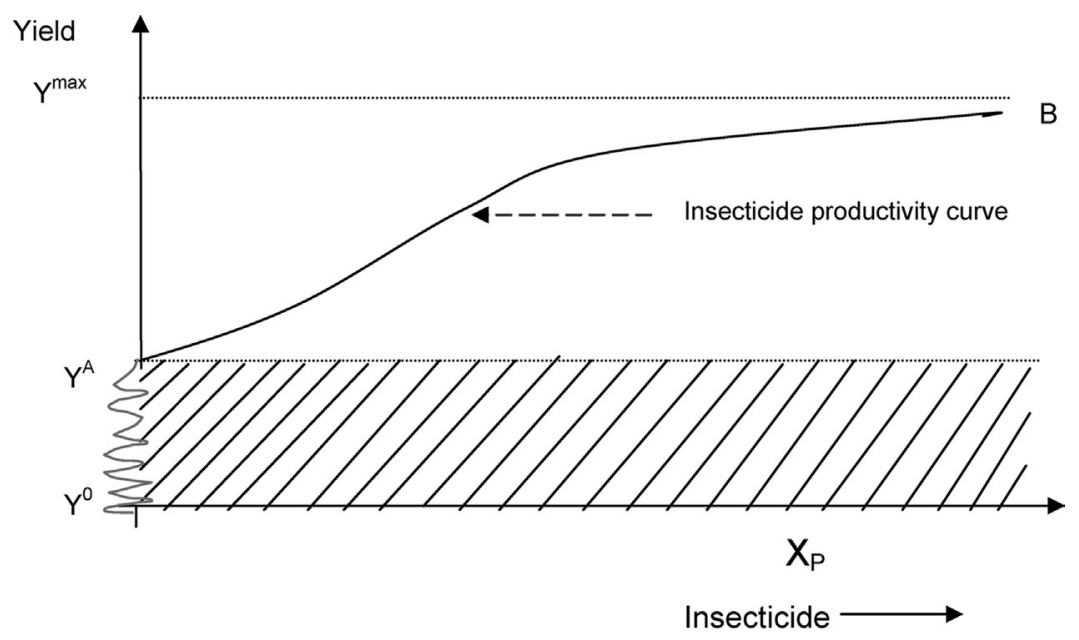

$$
\begin{array}{ll}
\mathrm{Y}^{\max }=\text { Maximum attainable yield } & \mathrm{Y}^{\mathrm{A}}=\text { Actual yield when insecticide is not used } \\
\mathrm{X}_{\mathrm{P}}=\text { Insecticide inputs } & \mathrm{B}=\text { Cumulative yield loss abatement function } \\
\mathrm{Y}^{0}=\text { Complete yield loss or zero yield arising from the most severe attack by insects }
\end{array}
$$

Figure 1 Impact of insecticides on production, yield loss and economic importance of chemical use under different levels of natural biological capital resources

down into two components: the shaded area between $\mathrm{Y}^{0}$ and $\mathrm{Y}^{\mathrm{A}}$ and between $\mathrm{Y}^{\mathrm{A}}$ and $\mathrm{Y}^{\max }$. The first component or the shaded area between $\mathrm{Y}^{0}$ and $\mathrm{Y}^{\mathrm{A}}$ represents the yield that a farmer obtains under natural pest control ('do nothing') where no insecticide is used at all. The shaded area is denoted by a collapsible line indicating that its magnitude varies depending on the type ('state') of a given ecosystem and the effectiveness of its self-regulatory mechanisms. The second component lying between $\mathrm{Y}^{\mathrm{A}}$ and $\mathrm{Y}^{\mathrm{max}}$ represents the maximum yield loss that can be possibly saved through the application of insecticides, i.e. the frontier of insecticide productivity. It represents the maximum 'increase' in output that can be achieved with insecticide use. In ecosystems that have high biological (bio-diversity) capital and effective self-regulation, the gap between $Y^{\mathrm{A}}$ and $\mathrm{Y}^{\mathrm{max}}$ will be small and the economic productivity of insecticides will be minimal. With continuous use of chemicals and weakening of the natural regulatory mechanisms over time, due for example to a reduction in the population of beneficial organisms, the shaded area will decrease (i.e. the actual yield $\mathrm{Y}^{\mathrm{A}}$ that a producer obtains without the use of insecticides will diminish). As a result, the gap between $\mathrm{Y}^{\max }$ and $\mathrm{Y}^{\mathrm{A}}$ will widen and the potential yield loss and hence the productivity of insecticides will increase commensurately. The above illustration shows that the economic importance and productivity of insecticides, level of insect attack and potential yield loss, and the state of biological regulatory mechanisms in an ecosystem are intimately linked together. It also shows that an understanding of the biological priors and ecological processes governing production systems is important in the estimation and interpretation of insecticide productivity (Carpentier \& Weaver, 1997). As a result, econometric models need to take cognisance of this linkage and interpret economic results of insecticide productivity in that context.

\section{Pest susceptibility (non-renewable) biological capital}

The second type of biological capital is nonrenewable and exists in the form of the susceptibility of pest species to available insecticides. Natural susceptibility of pests is a biological capital because it facilitates easier control of pests. An increase in the use of insecticides leads to higher selection pressure for resistant individuals within an insect population over time. Exposure of insect population to a specific insecticide or a combination of active ingredients with a similar mode of action kills the genetically 
more susceptible individuals in a population, leaving those with innate resistance to survive and reproduce to form a larger proportion of the gene pool in subsequent generations. ${ }^{1}$ The buildup of resistance gradually erodes the biological capital of pest susceptibility. Being a non-reversible process, the loss of insect susceptibility leads to increases in production costs in the future because greater quantities or new products (usually more expensive) will be required to achieve the same level of control of insects. Current decisions on insecticide use in a production system therefore have implications on the profit that would be obtained in the future (Hueth \& Regev, 1974).

\section{Effect of Biological Degradation on Productivity of Insecticides}

The depletion of both types of biological capital affects the productivity of insecticides in different ways. Loss of pest susceptibility or pest resistance reduces the productivity ('effectiveness') of insecticides whereas the loss of biodiversity increases it. The overall impact is determined by the net effect of insecticides on both renewable and non-renewable capital. Following Waibel and Setboonsarng (1993), inter-temporal linkages between an ecosystem's biological capital and the productivity of insecticides is illustrated in Figure $2 \mathrm{a}$ and $2 \mathrm{~b}$.

In Figure 2a, representing ecosystems where no insecticide is used, $\mathrm{Y}_{0}^{+S}$ is the yield obtained in a sprayed field while $\mathrm{Y}_{0}^{-\mathrm{S}}$ represents yield in unsprayed fields at an initial period $t_{0}$. The yield difference between sprayed and unsprayed fields denoted by ' $A$ ' is small because of internal self-regulation to control pests in the system is effective. As a result, the economic importance of insecticides is relatively small. At a later period, say $t_{1}$, the situation will be relatively similar because the biological capital which contributes to internal mechanisms to regulate insect damage remains intact over time. But in Figure 2b, representing ecosystems in which insecticides are used continuously over a long period of time, the biological capital would be compromised and self-regulatory mechanism weakened compared with Figure 2a. As a result, in later periods, say $t_{1}$, the yield in non-sprayed fields will decrease to $Y_{1}^{-S}$ and yield gap between sprayed and unsprayed fields will

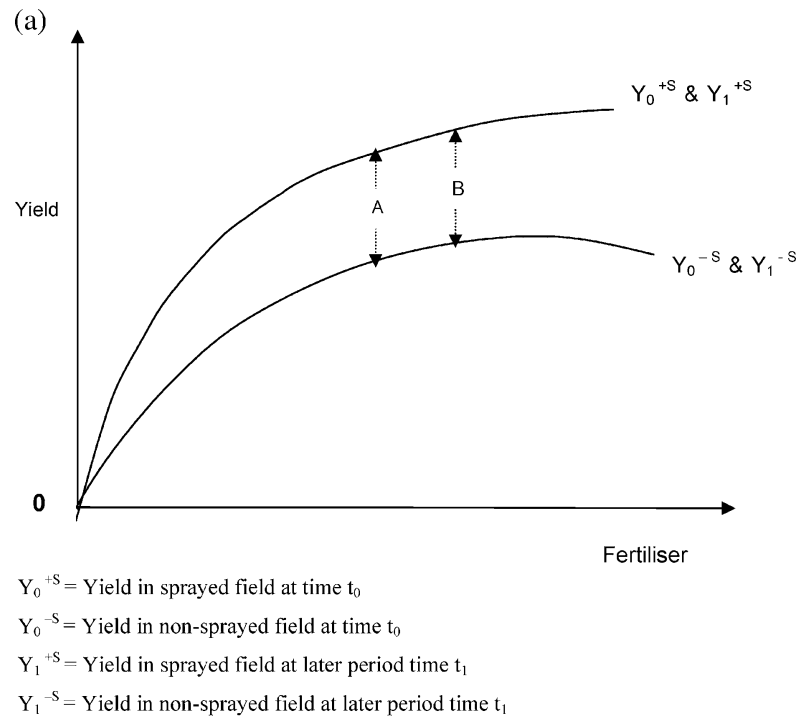

(b)

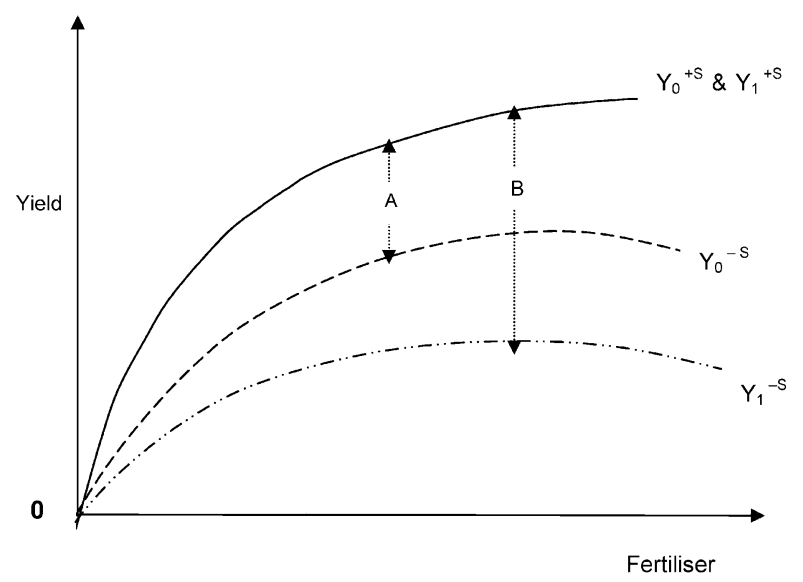

$\mathrm{Y}_{0}{ }^{+\mathrm{S}}=$ Yield in sprayed field at time $\mathrm{t}_{0}$

$\mathrm{Y}_{0}{ }^{-\mathrm{S}}=$ Yield in non-sprayed field at time $\mathrm{t}_{0}$

$\mathrm{Y}_{1}{ }^{+\mathrm{s}}=$ Yield in sprayed field at later period time $\mathrm{t}_{1}$

$Y_{1}{ }^{-s}=$ Yield in non-sprayed field at later period time $t_{1}$

Figure 2 (a) Economic importance of insecticide usage in ecosystems whose biological capital remains relatively intact. (b) Economic importance of insecticide usage in ecosystems whose biological capital has degraded over time

increase from A to B and the productivity of insecticides will increase accordingly. The magnitude of the yield difference depends on the extent of degradation of the biological capital and changes that have occurred in the state of ecosystem.

If observations from the two types of ecosystems are grouped together into a unique production function and a single productivity estimate of insecticide obtained, the results can 
be misleading. Differences in the biological capital of data observations can be a source of bias in insecticide productivity studies (Carpentier \& Weaver, 1997). To minimise estimation bias, field data may be stratified into sub-groups of observations having relatively similar insecticide use history and biological capital stock. Such stratification should reflect differences in the duration and intensity of insecticide use while accounting for other factors such as farmers' learning experience with insecticides. Fitting production models to the quasi-homogenous groups of observations is expected to provide results that reveal possible changes in biological capital and insecticide productivity over time and be more plausible for economic interpretation.

\section{Data and Analytical Method}

\section{The study area and cotton development policies}

The study area is part of the 'Great North' (Le Grand Nord) of Côte d'Ivoire and located between latitude $8^{\circ}$ and $9^{\circ}$ North and longitude $5^{\circ}$ and $6^{\circ}$ West. Annual rainfall of about $1200 \mathrm{~mm}$ decreases from the south to the north of the study area. The agricultural economy is dominated by crop production, with livestock being a minor activity.

Historically, there has been a wide gap in the economic opportunities between the richer southern and the less prosperous northern half of Côte d'Ivoire (Aubertin, 1983). For reasons of socio-political expediency and to incite farmers' interest in the (then) new crop, the government decided to promote cotton as a key cash crop (the 'white gold') in the northern region to redress this gap. A key element in the promotion of cotton cultivation was the distribution of free insecticides (100\% subsidy) to farmers on a standard dose for every hectare of cotton cultivated. Through this policy and other institutional supports, Côte d'Ivoire emerged as a top producer of cotton and one of the greatest consumers of insecticides in Africa. These policies and institutional supports are described in more detail elsewhere (Ajayi, 2000). Most of the increase in cotton production however was achieved by increasing the area cultivated rather than increases in yield per hectare of cultivated land. To take advantage of the generous government support to cotton growers, farmers in different geographical areas of Côte d'Ivoire started to cultivate cotton (and simultaneously use insecticides) at different points in time. Beginning from geographical locations that were the original target areas for cotton development, the cultivation of the crop spread gradually southwards into the fringes of the forest zone. Due to the policy of free distribution of insecticides, the introduction of cotton crop in a given geographical zone coincides with the beginning of insecticide use in that zone. Due to the differences in the length of period of exposure to insecticides, it is expected that the extent of biological degradation and productivity of insecticides in cotton fields will vary in the different cotton producing zones.

\section{Sampling technique}

Historical data on insecticide use and cropping systems were collected from the para-state cotton development agency CIDT (Compagne Ivoirienne pour le Développement de Textiles et Fibres). National vegetation and population distribution maps of Côte d'Ivoire were consulted and on this basis, all the cotton growing zones were categorised into quasi-homogenous groups having relatively common soil, vegetation and human population culture. Two research zones were selected for the study from the cotton zones. The first zone is the 'long history' (LH) zone representing zones where cotton was first introduced and where insecticides have been used continuously for a long time (about 40 years). The second zone is the short history (SH) zone representing geographical locations where cotton (and use of insecticides) was introduced at a more recent period of about 20 years ago or less. This approach assumes that cotton fields in the $\mathrm{SH}$ zone represents a baseline from where cotton production in the $\mathrm{LH}$ zone had previously taken off. This stratification method is expected to account for the slow and imperceptible changes that are expected to occur within the agroecosystem that has been subjected to continuous use of insecticides. For each selected zone, a sampling frame of cotton-growing villages was obtained from CIDT regional offices. From the list, five villages (three from $\mathrm{SH}$ and two from LH) were selected at random. In each village, 33 farmers ${ }^{2}$ were selected to make a total sample of 165 farmers. These farmers cultivated a total of 193 cotton fields all of which were monitored throughout the 1997/1998 farming season. 


\section{Data collection}

An enumerator was assigned to each study village and resided there to monitor farm operations and collect information on production inputs, outputs, household demography, use of insecticides, spraying practices and other information throughout the farming season. Crosssectional inputs and outputs data were collected from 193 cotton fields in the two research zones using a combination of structured questionnaires and direct measurements of important variables. The agro-economic data were collected through multiple visit approach and information summarised weekly for each cotton field. The data collected include labour inputs by type (men, women and children) and source (family, hired or exchange), fertiliser type and quantity, and insecticides (type, quantity and cost). The field operation on insecticide spraying was monitored to collect information on type and quantity of insecticides used, duration of spraying (exposure) and protective clothing worn by sprayers. In addition, a survey was carried out to assess farmers' knowledge, attitude and practices on insecticide and herbicide use. Given the irregular shape of farmers' field and the need for accurate information on the field sizes, all the cotton fields where agro-economic data were collected were measured with a pair of compasses and tapes. Fields for which closing error exceeded $5 \%$ were remeasured. At the time of this study, the cotton company had absolute monopoly on cotton market in the study area and was responsible for determining the grade of cotton and fixing the price for each grade throughout the country. Information on cotton output (grade and monetary value) produced in each selected field was obtained from the cotton development company based on the crop marketing transactions recorded on individual farmer's carnet (card) at the end of the marketing season. We did not specifically collect weather information as part of the study, but there is no indication that the weather during the year of the study was critically different from the ones in the past few years.

\section{Empirical specification of model}

This study emphasises the interpretation of productivity estimates in the context of the inter-temporal changes that are expected to occur in the natural biological resource base of the production systems over time. In the study, different functional forms - damage abatement and Cobb-Douglas function models - were fitted to the data.

\section{Description of variables}

Following Carrasco-Tauber and Moffit (1992), data for the variables used by Headley (1968) were the ones included in the models for this present study. Most of the variables are expressed in monetary values so that monetary returns per unit cost invested on the inputs can be directly estimated.

$\mathbf{Q}$ is the dependent variable representing the value of cotton production per hectare for each selected field. By expressing the dependent variable in monetary value, it ensures that both physical quantity and quality (grading premium) aspects of cotton production are integrated into a single variable. This was done because ignoring quality considerations of farm output can lead to substantial under-estimations of the productivity of insecticides (Babcock et al., 1992). This is particularly true for cotton where there is a distinct price premium for different quality grades of produce. During the study, the price for different grades of cotton is fixed by the cotton company CIDT and remains the same throughout the country.

FERTILISER is the variable representing the monetary value of the inorganic fertiliser used for the season measured in the local currency (in CFA) per ha. ${ }^{3}$ Due to measurement problems, the variable did not include the value of organic and farm yard manure that some farmers applied on their farms.

LABOUR is the total monetary equivalence of all the total labour inputs used per hectare for all farm operations from land preparation to harvesting operation in each selected field throughout the agricultural season. Although the labour inputs supplied by the farm family and communal sources were not paid for directly, they were valued at their opportunity costs. For labour inputs contributed by hired labour source, the amount of wages paid was used. Variable 'labour' is an aggregation of the costs of the three types of labour.

HERBICIDE was measured as the total expenditure (in CFA) on herbicides per hectare that were applied in the field during the farm season.

AGE refers to the age of head of the households selected for the study. This variable is used as a proxy for farm experience and management 
Table 1 Mean values of key inputs used in cotton production

\begin{tabular}{||l|c|c|c||}
\hline \hline Description & Long history zone & Short history zone & Pr $>|\boldsymbol{T}|$ \\
\hline Average field size (ha) & 3.25 & 1.85 & 0.0001 \\
\hline Cotton yield (CFA/ha) & 206,846 & 146,186 & 0.0001 \\
\hline Fertiliser (CFA/ha) & 35,545 & 28,434 & 0.0054 \\
\hline Labour (CFA/ha) & 83,612 & 69,572 & 0.0259 \\
\hline Herbicide (CFA/ha) & 10,470 & 3207 & 0.0001 \\
\hline Insecticide (CFA/ha) & 20,229 & 21,600 & 0.1384 \\
\hline All pesticides (CFA/ha) & 30,697 & 24,805 & 0.0004 \\
\hline Average insecticide use per field (CFA) & 61,917 & 25,303 & 0.0001 \\
\hline
\end{tabular}

capacity of the farmer because individuals in the study area are introduced to farming early in their youth. Educational status was not included in the model because little variation has been found in the sample population across the two study zones.

INSECTICIDE is the amount of expenditure (in CFA) on insecticides that were applied per hectare in the selected cotton fields during the season. This was obtained from the aggregation of the weekly records of the type and quantity of insecticides used in each field.

FLDAREA is the size (in hectares) of the monitored cotton field as measured by the pair of compasses and tape.

Variables such as the value of seed input was not included in the model because cotton seeds were supplied free of charge to all farmers by the cotton development company CIDT at a standard seed rate per hectare. Management variables like the level of education of farmers were not included because there is minimal variation in the level of formal education attained by farmers in the study area. Capital and machinery were not included as variables in the model because the farmers did not have building structures or machines. Farm capital does not vary much as it consisted primarily of hoes and axes and in some cases animals/oxen and its accessory implements.

\section{Result and Discussion}

\section{Determinants of cotton output}

Results show that fertilisers, labour inputs, field size and insecticides are the significant determinants of cotton output in the two study zones (Appendix 1). The appendix also shows that the coefficient of labour is higher in the $\mathrm{SH}$ zone. The reason for this is because of the significantly lower quantity of labour used per cultivated area in the zone (Table 1). Herbicide does not have a significant influence on cotton production in either of the zones. An explanation for this is that while herbicides reduce potential yield loss from weeds, they also contribute to reduction of labour inputs required for weeding. Herbicides applied in the study area are pre-emergence, and their contributions are best interpreted with respect to their role as labour saving input. The non-significance of herbicide is due to the greater effect of the direct labour inputs that were used in the two zones. In addition, herbicide was comparatively more expensive than the cost of hiring labour in the two zones.

\section{Response of cotton production to insecticide}

The coefficient of insecticides in the CobbDouglas model for example shows that a $1 \%$ increase in insecticide expenditure in cotton fields will increase the value of cotton output by $0.46 \%$ in the zone with long pesticide use and $0.48 \%$ in the zone where cotton and (therefore) insecticide use began more recently. The greater use of insecticide in the long history zone has slightly slowed down response to the chemical compared with the short history zone. The rate is however very small, estimated at less than two percentage points. The reason for the moderate change in insecticide response (and indications of pest resistance) may be due to several official measures that are being taken to control the initial indications of the emergence of pest 
resistance in the cotton zones of. Such initiatives include the West African regional network on Insecticide Resistance Management (IRM) strategy that was established to manage the resistance of pests (particularly Helicoverpa armigera) across the West African cotton production zones. The details of the IRM initiative are described elsewhere (Martin et al., 2000, 2005).

\section{Estimates of the marginal value product of insecticide}

The estimates of marginal value product of insecticide (Table 2) show that the value of a unit cost of investment on insecticides ranges between 2.50 and 4.70 for three out of the five functional model specifications. This implies that farmers obtain between 2.5 and 4.7 CFA for every CFA spent on insecticides. Interpreted in a strictly economic terms, farmers can get higher monetary returns per unit investment cost on the chemical. Although, two of the damage functional model specification provide estimates of marginal value product that is less than 1, suggesting that insecticides are over used. Overall, the result shows that the divergence between insecticide productivity estimates on one hand and, public concern that insecticides are overused on the other hand may not be attributed exclusively to functional specification issues. The result is similar to that obtained in earlier studies (Carpentier \& Weaver, 1997; Carrasco-Tauber \& Moffit, 1992). The paradox most probably lies in the dis-aggregation of the results and interpretation of the same within the context of the type of production systems in the two zones.

A disaggregation of the marginal value products of insecticide (Table 2) shows that the marginal value products and economic importance of insecticides are consistently higher in the long history zone. There are two explanations
Table 3 Distribution of total farm size by type of crop cultivated

\begin{tabular}{|l|c|c||}
\hline \multirow{2}{*}{ Type of field } & \multicolumn{2}{|c|}{ Percent of total farm size } \\
\cline { 2 - 3 } & Long history & Short history \\
\hline Cotton & 51 & 31 \\
\hline Lowland rice & 6 & 2 \\
\hline Upland rice & 15 & 10 \\
\hline Maize & 15 & 13 \\
\hline Ground nut & 6 & 7 \\
\hline Cashew & 3 & 17 \\
\hline Yam & 1 & 17 \\
\hline Other crops & 3 & 3 \\
\hline Total & 100 & 100 \\
\hline
\end{tabular}

Source: Field measurement and survey.

for this. First, the continuous use of insecticide in the long history zone may have lowered the biological (bio-diversity) capital and self-regulatory processes in the zone, thus creating a wide gap between potential and actual crop yield (potential yield loss) and thereby increasing the economic importance of insecticide in the zone. The possibility of reduced bio-diversity is supported by the marked differences in the crop diversity in the two zones.

Results show that fields in the LH zone have less crop diversity and are generally more specialised compared with fields in the $\mathrm{SH}$ zone. In the LH zone, two crops (cotton and rice) alone account for $72 \%$ of the total crop area while in the $\mathrm{SH}$ zone, these two crops account for only $44 \%$ of total cultivated indicating that farming is more diversified in the $\mathrm{SH}$ zone (Table 3). In general, the proportion of the area grown to cotton (relative to total area grown to all crops) and crop diversity decreases from the $\mathrm{LH}$ zone to the $\mathrm{SH}$ zone. The gradual displacement of other crops by cotton over several years may contribute to the narrowing of the crop

Table 2 Marginal value product of insecticides and other major farm inputs

\begin{tabular}{|c|c|c|c|c|c|c|c|c|c|c|}
\hline \multirow[t]{3}{*}{ Farm input } & \multirow{2}{*}{\multicolumn{2}{|c|}{ Cobb-Douglas }} & \multicolumn{8}{|c|}{ Damage function specifications } \\
\hline & & & \multicolumn{2}{|c|}{ Exponential } & \multicolumn{2}{|c|}{ Logistic } & \multicolumn{2}{|c|}{ Weibull } & \multicolumn{2}{|c|}{ Pareto } \\
\hline & $\begin{array}{c}\text { Long } \\
\text { history }\end{array}$ & $\begin{array}{c}\text { Short } \\
\text { history }\end{array}$ & $\begin{array}{c}\text { Long } \\
\text { history }\end{array}$ & $\begin{array}{c}\text { Short } \\
\text { history }\end{array}$ & $\begin{array}{c}\text { Long } \\
\text { history }\end{array}$ & $\begin{array}{c}\text { Short } \\
\text { history }\end{array}$ & $\begin{array}{c}\text { Long } \\
\text { history }\end{array}$ & $\begin{array}{c}\text { Short } \\
\text { history }\end{array}$ & $\begin{array}{c}\text { Long } \\
\text { history }\end{array}$ & $\begin{array}{c}\text { Short } \\
\text { history }\end{array}$ \\
\hline Insecticide (CFA/CFA) & 4.70 & 3.24 & 4.41 & 2.74 & $<0.1$ & $<0.1$ & 0.74 & 0.47 & 4.00 & 2.50 \\
\hline Fertiliser (CFA/CFA) & 0.95 & 0.91 & 0.99 & 0.94 & 0.93 & 0.96 & 1.33 & 1.21 & 1.02 & 0.95 \\
\hline Herbicide (CFA/CFA) & 0.08 & 0.38 & 0.07 & 0.33 & 0.08 & 0.24 & 0.12 & 0.39 & 0.08 & 0.31 \\
\hline
\end{tabular}

Note: Marginal value product figures are given in terms of CFA returns per CFA expenditure for each farm input. 
diversity and may have affected the level of biological diversity in the two zones.

The second explanation for the higher productivity of insecticide is the significantly higher use of yield increasing inputs (fertiliser and labour) in the LH zone. At zero level of fertiliser and labour use, the production curves begin from the origin and are the same in the two zones. But as more fertiliser and labour is used, the attainable yield increases and the difference between the output curves (and also the absolute quantity of potential yield loss) in the two zones will widen.

\section{Summary and Conclusion}

The study demonstrates how agricultural development policies have affected the historical path of cotton production with potentials to cause inadvertent effects on agricultural sustainability. This study estimated marginal value product of insecticide and shows the value of a unit cost of investment on insecticides ranges between 2.50 and 4.70 for three out of the five functional model specifications. The result shows that the divergence between insecticide productivity estimates on one hand and, public concern that insecticides are overused on the other hand may not be attributed exclusively to functional specification of estimation models. However, some insights into resolving the paradox can be gained through disaggregation of the estimates (e.g. by chemical use history) and interpreting them in the context of the inter-temporal changes that have occurred in the biological capital of production systems over time. A disaggregation of the marginal value products of insecticide by chemical use history shows that in the zones where insecticides have been used for a longer period and crop diversity is narrower, the marginal value products of insecticides are consistently higher due to lower biodiversity which raises the economic importance of the chemical in such zones.

The official practice of recommending same standard application of quantity of insecticides based on prophylactic regimes per unit cotton across the entire cotton producing regions in the country is less appropriate. The system has been widely criticised for promoting excessive use of pesticides via its recommendation regime of six fortnightly applications, irrespective of need.
There is need for targeted insecticide management practices that takes cognizance of the differences in the amount of biological capital and the economic value of the potential crop yield that would be saved by the chemical application in the different production systems. This can be done through the promotion of insect management techniques (e.g. IPM and threshold-based interventions) that have been found to preserve the renewable biological capital of production systems through reduction in insecticide usage by $40-50 \%$, and yet increase cotton yield by $100-200 \mathrm{~kg} \mathrm{ha}^{-1}$ (Silvie et al., 2001). In this regard, sustainable methods for managing cotton pests that were identified in previous field trials in Côte d'Ivoire (Angelini \& Couilloud, 1972; Angelini et al., 1980) should be revisited and encouraged.

If pest numbers are available and other factors affecting farm production are similar, then differences in the marginal productivity of insecticides in fields located in different ecosystems will readily provide indication of a change in the level of biological capital. The lack of entomological surveys of pests, their predators and the indication of their resistance (e.g. LD50 test) is a major limitation of this study that should be corrected in similar studies in the future. Detailed information regarding the state of the agroecosystem being studied should be collected concurrently with agro-economic data and these should be integrated into models for estimating insecticides' productivity. Availability of these types of data will both increase the explanatory powers of econometric models, and provide further insights into the interpretation of economic estimates of insecticide productivity, e.g. economic productivity of insecticide due to lowered biodiversity as distinguished from the one due to the use of yield increasing inputs.

Panel data consisting of cross-sectional observations recorded repeatedly over a number of years will provide more opportunities for assessing the situation on insecticide use in the cotton zone and making appropriate policy recommendations.

\section{Correspondence}

Any correspondence should be directed to Oluyede Clifford Ajayi, Agricultural Economist, International Centre for Research in Agroforestry (ICRAF), c/o Chitedze Agricultural Research Station, P.O. Box 30798, Lilongwe 03, Malawi (ajayi@gmx.net). 


\section{Notes}

1. The author gratefully acknowledges the clarification given by one of the anonymous reviewers.

2. This figure ensured that a statistical a minimum number of observations is available per village even after making provision of possible drop out of farmers during data collection. However, no farmer dropped out during the course of data collection.

3. The exchange rate at the time of the field study was $\mathrm{US} \$=500 \mathrm{CFA}$.

\section{References}

Ajayi, O.C. (2000) Pesticide Practices, Productivity and Farmers' Health: The Case of Cotton-Rice Systems in Côte d'Ivoire. Pesticide Policy Project Series No. 3, Hannover, University of Hannover Publications, Germany: ISBN: 3-934373-03-8.

Altieri, M.A. (1993) Ethno science and biodiversity: Key elements in the design of sustainable pest management systems for small farmers in developing countries. Agriculture, Ecosystems and Environment 46, 257-272.

Angelini, A. and Couilloud, R. (1972) Les moyens de lutte biologique contre certains ravageurs du cotonnier et une perspective sur la lutte intégrée en Côte d'Ivoire. Coton et Fibres Tropicales 27 (3), 283-289.

Angelini, A., Descoins, C., le Rumeur, C. and Lhoste, J. (1980) Nouveaux résultats obtenus avec un attractif sexuel de cryptophlebia leucotreta. Coton et Fibre Tropicale 35 (3), 277-281.

Aubertin, C. (1983) Histoire et création d'une région sous développée: le nord ivorien. Cahier ORSTOMSérie Humaines 19 (1), 23-57.

Babcock, B.A., Lichtenberg, E. and Zilberman, D. (1992) Impact of damage control and quality of output: Estimating pest control effectiveness. American Journal of Agricultural Economics 74, 163-172.

Blackwell, M. and Pagoulatos, A. (1992) The econometrics of damage control. American Journal of Agricultural Economics 1040-1044.

Campbell, H.F. (1976) Estimating the marginal productivity of agricultural pesticides: The case of tree-fruit farms in the Okanagan Valley. Canadian Journal of Agricultural Economics 24 (2), 23-30.

Carpentier, A. and Weaver, R.D. (1997) Damage control productivity: Why econometrics matters. American Journal of Agricultural Economics 79, 47-61.

Carrasco-Tauber, C. and Moffit L.J. (1992) Damage control econometrics: Functional specification and pesticide productivity. American Journal of Agricultural Economics 74, 158-162.

Headley, J.C. (1968) Estimating the productivity of agricultural pesticides. American Journal of Agricultural Economics 50, 13-23.

Hueth, D. and Regev, U. (1974) Optimal agricultural pest management with increasing pest resistance. American Journal of Agricultural Economics $56,543-552$.

Hurd, B.H. (1994) Yield response and production risk: An analysis of integrated pest management in cotton. Journal of Agricultural and Resource Economics 19 (2), 313-326.

Lichtenberg, E. and Zilberman, D. (1986) The econometrics of damage control: Why specification matters. American Journal of Agricultural Economics 68, 261-273.

Martin, T., Ochou, G.O., Djihinto, A., Traore, D., Togola, M., Vassal, J.M., Vaissayre, M. and Fournier, D. (2005) Controlling an insecticide-resistant bollworm in west Africa. Agriculture, Ecosystems and Environment 107, 409-411.

Martin, T., Ochou, O.G., Hala N'Klo, F., Vassal, J.M. and Vaissayre, M. (2000) Pyrethroid resistance in the cotton bollworm Helicoverpa armigera in West Africa. Pest Management Science 56, 549-554.

Mclaughlin, A. and Mineau, P. (1995) Impacts of agricultural practices on biodiversity. Agriculture, Ecosystems and Environment 55, 201-212.

Mumford, J.D. (1981) A study of sugar beet growers' pest control decisions. Annals of Applied Biology 97, 243-252.

Pannell, D.J. (1991) Pests and pesticides, risk and risk aversion. Agricultural Economics 5, 361-383.

Pimental, D., McLaughlin, L., Zepp, A., Lakitan, B., Kraus, T., Kleinman, P., Vancini, F., Roach, W.J., Graap, E., Keeton, W.S. and Selig, G. (1993) Environmental and economic impacts of reducing US agricultural pesticide use. In D. Pimental and H. Lehman (eds) The Pesticide Question: Environment, Economics and Ethics. New York, London: Chapman Hall.

Qaim, M. and Zilberman, D. (2003) Yield effects of genetically modified crops in developing countries. Science 299, 900-902.

Qaim, M. (2003) Bt Cotton in India: Field trial results and economic projections. World Development 31 (12), 2115-2127.

Regev, U. (1988) Economics of sustainable pest control. In J.S. Yaninek and H.R. Herren (eds) Biological Control: A Sustainable Solution to Crop Pest Problems in Africa (pp. 97-111). Ibadan, Nigeria: International Institute of Tropical Agriculture.

Relyea, R.A. (2005) The impact of insecticides and herbicides on the biodiversity and productivity of aquatic communities. Ecological Applications 15 (2), 618-627.

Rola, A.C. and Pingali, P.L. (1993) Pesticides, Rice Productivity, and Farmers' Health-An Economic Assessment. Manila, Philippines: IRRI.

Silvie, P., Deguine, J.P., Nibouche, S., Michel, B. and Vaissayre, M. (2001) Potential of threshol-based interventions for cotton pest control by small farmers in west Africa. Crop Protection 20, 297-301.

Waibel, H. and Setboonsarng, S. (1993) Resource degradation due to chemical inputs in vegetablebased farming systems of Thailand. Journal of Asian Farming Systems Association 2, 107-120. 


\section{Appendix 1}

Table A1 Production coefficients for different functional model specifications

\begin{tabular}{|c|c|c|c|c|c|c|c|c|c|c|}
\hline \multirow[t]{3}{*}{ Variable } & \multirow{2}{*}{\multicolumn{2}{|c|}{ Cobb-Douglas }} & \multicolumn{8}{|c|}{ Damage function specifications } \\
\hline & & & \multicolumn{2}{|c|}{ Exponential } & \multicolumn{2}{|c|}{ Logistic } & \multicolumn{2}{|c|}{ Weibull } & \multicolumn{2}{|c|}{ Pareto } \\
\hline & $\begin{array}{c}\text { Long } \\
\text { history }\end{array}$ & $\begin{array}{c}\text { Short } \\
\text { history }\end{array}$ & $\begin{array}{c}\text { Long } \\
\text { history }\end{array}$ & $\begin{array}{c}\text { Short } \\
\text { history }\end{array}$ & $\begin{array}{c}\text { Long } \\
\text { history }\end{array}$ & $\begin{array}{c}\text { Short } \\
\text { history }\end{array}$ & $\begin{array}{c}\text { Long } \\
\text { history }\end{array}$ & $\begin{array}{c}\text { Short } \\
\text { history }\end{array}$ & $\begin{array}{c}\text { Long } \\
\text { history }\end{array}$ & $\begin{array}{c}\text { Short } \\
\text { history }\end{array}$ \\
\hline Intercept & $\begin{array}{c}2.5219 \\
(1.57)\end{array}$ & $\begin{array}{c}0.6427 \\
(0.36)\end{array}$ & $\begin{array}{c}7.2469 \\
(4.41)\end{array}$ & $\begin{array}{l}5.4208 \\
(4.17)\end{array}$ & $\begin{array}{r}3.4567 \\
(3.98)\end{array}$ & $\begin{array}{c}2.8233 \\
(4.03)\end{array}$ & $\begin{array}{c}2.5426 \\
(1.03)\end{array}$ & $\begin{array}{c}3.0983 \\
(1.63)\end{array}$ & $\begin{array}{c}9.7453 \\
(<0.01)\end{array}$ & $\begin{array}{c}3.2860 \\
(3.45)\end{array}$ \\
\hline $\begin{array}{l}\text { Fertiliser } \\
\text { (CFA/ha) }\end{array}$ & $\begin{array}{c}0.1633 \\
(1.64) \\
\end{array}$ & $\begin{array}{c}0.1771 \\
(2.42)\end{array}$ & $\begin{array}{c}0.1701 \\
(1.69)\end{array}$ & $\begin{array}{c}0.1831 \\
(2.52)\end{array}$ & $\begin{array}{c}0.1603 \\
(1.59)\end{array}$ & $\begin{array}{c}0.1865 \\
(2.55)\end{array}$ & $\begin{array}{c}0.2286 \\
(2.22) \\
\end{array}$ & $\begin{array}{c}0.2354 \\
(3.14)\end{array}$ & $\begin{array}{c}0.1746 \\
(1.71)\end{array}$ & $\begin{array}{c}0.1857 \\
(2.54)\end{array}$ \\
\hline $\begin{array}{l}\text { Labour } \\
\text { (CFA/ha) }\end{array}$ & $\begin{array}{c}0.2458 \\
(1.69)\end{array}$ & $\begin{array}{c}0.4609 \\
(4.10)\end{array}$ & $\begin{array}{l}0.2563 \\
(1.75)\end{array}$ & $\begin{array}{c}0.4772 \\
(4.30)\end{array}$ & $\begin{array}{c}0.2442 \\
(1.66)\end{array}$ & $\begin{array}{c}0.4988 \\
(4.55)\end{array}$ & $\begin{array}{c}0.3450 \\
(2.32)\end{array}$ & $\begin{array}{c}0.4864 \\
(4.13)\end{array}$ & $\begin{array}{c}0.2613 \\
(1.77)\end{array}$ & $\begin{array}{c}0.4758 \\
(4.27)\end{array}$ \\
\hline $\begin{array}{l}\text { Herbicide } \\
\text { (CFA/ha) }\end{array}$ & $\begin{array}{c}0.0039 \\
(0.39) \\
\end{array}$ & $\begin{array}{c}0.0084 \\
(0.67) \\
\end{array}$ & $\begin{array}{c}0.0033 \\
(0.33)\end{array}$ & $\begin{array}{c}0.0073 \\
(0.59)\end{array}$ & $\begin{array}{c}0.0039 \\
(0.39)\end{array}$ & $\begin{array}{c}0.0052 \\
(0.42)\end{array}$ & $\begin{array}{c}0.0062 \\
(0.59)\end{array}$ & $\begin{array}{c}0.0085 \\
(0.65)\end{array}$ & $\begin{array}{c}0.0039 \\
(0.39)\end{array}$ & $\begin{array}{c}0.0069 \\
(0.55)\end{array}$ \\
\hline $\begin{array}{l}\text { Farmers' } \\
\text { age }\end{array}$ & $\begin{array}{c}0.0899 \\
(0.85)\end{array}$ & $\begin{array}{c}-0.1361 \\
(-0.91)\end{array}$ & $\begin{array}{c}0.0671 \\
(0.63)\end{array}$ & $\begin{array}{l}-0.1352 \\
(-0.92)\end{array}$ & $\begin{array}{c}0.0906 \\
(0.82)\end{array}$ & $\begin{array}{c}-0.1224 \\
(-0.84)\end{array}$ & $\begin{array}{c}0.0785 \\
(0.68)\end{array}$ & $\begin{array}{c}-0.2214 \\
(-1.46)\end{array}$ & $\begin{array}{c}0.0784 \\
(0.70)\end{array}$ & $\begin{array}{l}-0.1328 \\
(-0.90)\end{array}$ \\
\hline Field area & $\begin{array}{c}0.2978 \\
(3.70)\end{array}$ & $\begin{array}{c}0.2183 \\
(3.27)\end{array}$ & $\begin{array}{l}0.2935 \\
(3.62)\end{array}$ & $\begin{array}{l}0.2190 \\
(3.32)\end{array}$ & $\begin{array}{c}0.2998 \\
(3.70)\end{array}$ & $\begin{array}{c}0.2210 \\
(3.38)\end{array}$ & $\begin{array}{c}0.2696 \\
(3.19)\end{array}$ & $\begin{array}{c}0.2107 \\
(3.05)\end{array}$ & $\begin{array}{c}0.2922 \\
(3.57)\end{array}$ & $\begin{array}{l}0.2203 \\
(3.33)\end{array}$ \\
\hline $\begin{array}{l}\text { Insecticide } \\
\text { (CFA/ha) }\end{array}$ & $\begin{array}{c}0.4593 \\
(3.32) \\
\end{array}$ & $\begin{array}{c}0.4789 \\
(3.29) \\
\end{array}$ & & & & & & & & \\
\hline Lambda $\lambda$ & & & $\begin{array}{c}7.4 \times 10^{-5} \\
(2.66)\end{array}$ & $\begin{array}{c}7.4 \times 10^{-5} \\
(2.59)\end{array}$ & & & & & $\begin{array}{c}0.0004 \\
(<0.01)\end{array}$ & $\begin{array}{c}0.6600 \\
(0.77)\end{array}$ \\
\hline Sigma $\sigma$ & & & & & $\begin{array}{c}0.0734 \\
(1.19)\end{array}$ & $\begin{array}{c}0.2501 \\
(2.50) \\
\end{array}$ & & & & \\
\hline$\mu$ & & & & & $\begin{array}{c}0.8406 \\
(1.77) \\
\end{array}$ & $\begin{array}{c}2.4258 \\
(2.45) \\
\end{array}$ & & & & \\
\hline K & & & & & & & & & $\begin{array}{c}1.5687 \\
(0.30) \\
\end{array}$ & $\begin{array}{l}4.5722 \\
(2.58) \\
\end{array}$ \\
\hline $\mathrm{C}$ & & & & & & & $\begin{array}{c}0.2509 \\
(0.09)\end{array}$ & $\begin{array}{c}0.2729 \\
(0.13) \\
\end{array}$ & & \\
\hline R-square & 0.45 & 0.52 & 0.44 & 0.53 & 0.45 & 0.54 & 0.39 & 0.48 & 0.44 & 0.53 \\
\hline
\end{tabular}

Note: The values in parentheses are the absolute $t$-values.

\section{Appendix 2}

Using the typical production equation

$\mathrm{Q}=\mathrm{A} \mathrm{Z}_{\mathrm{i}}^{\mathrm{bi}}$

$\mathrm{Q}=$ Output, $\mathrm{A}=$ Constant intercept term,

$\mathrm{Z}_{\mathrm{i}}=$ vector of production inputs,

$b_{i}=$ elasticity of production

If a distinction is made between insecticide inputs $X_{p}$ and other conventional production inputs $Z_{i}$ (as suggested by Lichtenberg \& Zilberman, 1986), equation (1) may be re-formulated as:

$$
Q=f\left[Z_{i}, G\left(X_{p}\right)\right] \quad \text { where } i=1,2,3, \ldots, n
$$

Expressing (2) in a more formal production equation, it becomes:

$$
\mathrm{Q}=\mathrm{A} Z_{\mathrm{i}}^{\beta \mathrm{i}}[\mathrm{G}(\mathrm{x})]^{\gamma}
$$

(1) where $G(x)$ is the damage function and other parameters remain as initially defined.

Following the assumption in previous studies (Carrasco-Tauber \& Moffit, 1994; Babcock et al., 1992), the control of pest damage is assumed to be proportional to the damage function $G(x)$ and thus, parameter $\gamma$ is restricted to unity. Expressed in logarithmic form, (3) is written explicitly as:

$$
\log \mathrm{Q}=\log \mathrm{A}+\beta_{\mathrm{i}} \log \mathrm{Z}_{\mathrm{i}}+\log [\mathrm{G}(\mathrm{x})]
$$


The function $\mathrm{G}(\mathrm{x})$ follows a cumulative probability distribution that can be expressed in different forms to be tested empirically. But given that the most appropriate function still remains unknown, all the four different specifications are used alternatively as shown below in (5) through (8) respectively.

$$
\begin{aligned}
& \text { Exponential: } \log \mathrm{Q}=\log \mathrm{A}+\beta_{\mathrm{i}} \log \mathrm{Z}_{\mathrm{i}} \\
& \quad+\log [1-\exp (-\lambda \mathrm{X})] \\
& \text { Logistic: } \log \mathrm{Q}=\log \mathrm{A}+\beta_{\mathrm{i}} \log \mathrm{Z}_{\mathrm{i}} \\
& \quad+\log [1+\exp (\mu-\sigma \mathrm{X})]^{-1}
\end{aligned}
$$

$$
\begin{aligned}
& \text { Weibull: } \log \mathrm{Q}=\log \mathrm{A}+\beta_{\mathrm{i}} \log \mathrm{Z}_{\mathrm{i}} \\
& \quad+\log \left[1-\exp \left(-\mathrm{X}^{\mathrm{c}}\right)\right] \\
& \text { Pareto: } \log \mathrm{Q}=\log \mathrm{A}+\beta_{\mathrm{i}} \log \mathrm{Z}_{\mathrm{i}} \\
& \left.\quad+\log \left[1-\mathrm{K}^{\lambda} \mathrm{X}^{-\lambda}\right)\right]
\end{aligned}
$$

$\beta_{\mathrm{i}}, \lambda, \mu, \sigma, \mathrm{K}$ and $\mathrm{C}$ are the parameters that are to be estimated from the results of the alternative model. The non-linear nature of the above equations makes it necessary that non-linear procedures are used to estimate the parameters. The marginal value products (MVPs) were estimated at the mean value of the variables 